\title{
Contesting neoliberal governance. The case of Romanian Roma
}

\author{
Ionuț-Marian Anghel ${ }^{12 *}$
}

${ }^{1}$ Romanian Academy, School for Advanced Studies, 125 Calea Victoriei, 010071 - Bucharest, Romania

2 Romanian Academy, Research Institute for Quality of Life, 13 Calea 13 Septembrie, 050711 - Bucharest, Romania

Neoliberalization

Roma

Minority Representation

Governance
ABSTRACT

The article delineates the shifting forms of minority governance that took shape after 1989 in solving Roma related affairs and its ambiguous effects on the ground. I argue that, after 1989, the new social and public policies adopted a more neoliberal trend in solving Romani affairs through processes of decentralization, public-private partnerships and mobilization of civil society (Roma) organizations as key tools for empowering and social inclusion of Romani communities, abandoning old governmental programs focused on discipline, control and policing. However, as we will see in the Romanian case, these processes and policies had ambiguous effects and often have gone together with a diminishing of democratic accountability and control of Roma related affairs by state/public institutions and with the devolution of responsibilities to non-governmental and human rights organizations, Roma representatives from public institutions and communities themselves (see also van Baar 2011a).

\section{Introduction}

Amnesty International's last report briefly remarks the current violation of human rights regarding Roma in Romania. Alongside discriminatory and

\footnotetext{
* Contact address: ionut.anghel@iccv.ro (Ionuț-Marian Anghel)
} 
stigmatizing speeches used by public officials ${ }^{1}$, recent cases of eviction or human rights violations are still unsolved. For example, in a north-western town, Baia Mare, a wall was erected in 2011 to separate a few blocks, inhabited mainly by Roma, from the rest of the residential area. Although the Council for Combating Discrimination stated that the wall was an obvious case of discrimination and recommended to be put down, a decision from the High Court of Cassation and Justice from 2013 cancelled that decision and the wall is still in place today. In Eforie Sud and Cluj-Napoca, many Romani families were forcibly evicted in extreme weather conditions, during the winter season. In Eforie Sud, more than 100 Roma (including 55 children) were relocated in 2013 in two abandoned school buildings with poor access to public utilities, while their former informal settlement were dismantled. (Amnesty International 2015, 303-304). The relocation of Roma on the outskirts or near a waste dump is a practice implemented by other local authorities, the most common example being the 300 Roma evicted from the centre of Cluj-Napoca in 2010 and relocated in Pata Rât, the city's waste dump. The same circumstance I observed in Alba Iulia, while I was doing fieldwork in 2015. While we can say that in Romania, there is no special attention from the mass media or political parties that could incite to hate speech or extremism regarding the Roma; this does not mean that in the last decade there were no hostile policies against them. The relocation of Roma from the centre of the cities, to the landfills or to substandard housing, belonging to the old abandoned industrial state-enterprises, subsequently converted into social housing without access to adequate public services is an example in this sense (Mionel 2013, Raț 2013).

Paradoxically, alongside these hostile policies, we have witnessed, after 1989, to numerous national and European wide programs to improve their situation. As van Baar observed, the new policies and programs which were articulated in post-socialist Central and Eastern Europe (CEE) were meant to 'empower and create opportunities for political, socio economic,

\footnotetext{
${ }^{1}$ Like the one used in 2010 by president Traian Băsescu on an official visit in Slovenia, when he stated that 'among nomad Roma, very few want to work, and many of them, traditionally, live off what they steal'.
} 
and cultural self-articulation and participation, [and] to improve and include marginalized [...] populations in culture and society in order to enhance wellbeing, community cohesion, security, standards of living, and justice' (2011a, 2).

The involvement of inter-governmental organizations (IGOs) and development agencies was a result of two processes that I will discuss below, namely (1) the changing of minority representation, from a nonEuropean to a European minority and (2) the changing processes and patterns of governing minority affairs. This article is divided into five parts. In the first part, questions of statehood and changing forms of governance at the EU level as a political consequence of EU integration are posed. In the second part, I describe the socialist mode of governing Roma related affairs, through two specific mechanisms: sedentarization and proletarization. In the first years of the regime, the Roma were framed as a dangerous minority that needed to be controlled and disciplined by entering the socialist mode of production. The framing of Roma as a 'social and demographic problem' rather than in ethnic terms, legitimated state intervention and depoliticized discrimination and low socio-economic mobility. The third part of the article analyses the transformations of social and public policies in post-socialist $\mathrm{CEE}$, as a result of the changing processes and patterns of European governance. If during the first decade after the fall of the Berlin Wall, EU pressured future Member States to adopt hard modes of governance to manage Roma related affairs, after 2000, the EU recommendations changed towards adopting softer modes of governance by the candidate states, to cope with the diversity among member states. In the fourth part of the article, I will show the pitfalls of this new modes of governance, arguing that more often than not this policies led to a diminishing of democratic accountability and control of Roma related affairs by public institutions and with the devolution of responsibilities to non-governmental and human rights organizations, Roma representatives from public institutions/Roma experts and communities themselves. The final part concludes that by dispersing responsibilities to this 'web of governance' (Clarke 2012), 
questions of democratic legitimacy regarding these soft modes of governance and a weak capacity of local authorities and NGOs to solve complex socio-economic problems are posed.

\section{From government to governance in European polity}

In the past two decades, there have been a lot of voices within the social and political sciences who criticized the conceptualization of state power in the hands of a central government that monopolizes the state authority. In this regard, several studies have begun to consider the role of non-state authorities, expert systems, quasi- and non-governmental organizations, informal and formal self-governance networks at national or even transnational level in developing and implementing public and social policies (Börzel 2011, Héritier and Rhodes 2011, Hooghe and Marks 2003, Bache and Flinders 2004). Thus, hierarchical government has been replaced by a type of multi-level governance, whereby responsibilities, tasks and activities that are to be governed are dispersed by the central government to sub-national (regional and local) institutions, civil society, private actors, but also at the supranational level, the latter gaining more power in elaborating policy frameworks. Thus, the concept of multi-level governance has both a vertical and a horizontal dimension: 'Multi-level refers to the increased inter-dependence of governments operating at different territorial levels, while governance signals the growing interdependence between governments and non-governmental actors at various territorial levels' (Bache and Flinders 2004, 3). The growing implication of non-governmental, local actors, private organizations and civil society institutions in the policy fabric was part of the EU's attempts to make the policy processes more inclusive and also to reduce its democratic deficit (see Shore 2011).

These new forms of governance have implications upon the state's role in a (post)modern era. According to some scholars, we are witnessing a 'hollowing out of the state apparatus' in which 'old and new state capacities [are] being reorganized territorially on subnational, national, supranational 
and translocal levels' (Jessop 2004, 64). The state's new role is related to steering or enabling the self-governance networks that are formed to solve punctual problems, rather than to command and control as specific to the old model of centralized nation-states. As a consequence, Jessop introduced the concept of meta-governance, or the governing of governance, to highlight the importance of public organizations to exert control over devolved and decentralized decision-making organizations (Jessop 1999, 2009). However, these studies of changing forms of governance reflect the transformations in the EU arena or in the Western states. Very few are focused on the CEE context (see for exceptions Börzel 2011, Héritier and Rhodes 2011, Hooghe and Marks 2001, Stubbs 2005) where forms of multilevel governance were assumed selectively by future member states in the context of European integration (Bruszt 2008). As Börzel has shown for the implementation of the acquis communautaire, the European Commission (EC) has explicitly requested the devolution of tasks and resources to civil society actors and local offices to enforce the legitimacy and efficiency of the whole process that would have had to go hand in hand with a decentralization of administrative and political power. Instead, the lack of qualified personnel at the subnational level has created asymmetrical power relationships, in which the acceding countries have participated passively in the policymaking, often receiving policy templates from top-down (Börzel 2011, 88).

The 'governance turn' (Kohler-Koch and Rittberger 2006) in minority related affairs will be my point of focus in this article. The devolution and sharing of power and competencies to subnational and supranational levels have provided institutional sites for recognizing non-state actors and even transnational populations such as Roma. Since the fall of socialism, many inter-governmental institutions and international non-governmental organizations (INGOs) have started framing Roma as a European minority and have financed local NGOs to deliver services that would be in consistence with their basic human and minority rights. The growing number of projects implemented by NGOs offered visibility to the situation of Roma and contributed to educating a Roma elite, supporting it to acquire 
the skills and expertise needed to participate in advocacy processes and decision making in public policies (Ram 2011). Later on, EC has introduced the public-private partnership in various programs to give voice to individuals in the processes of policymaking.

However, in this article, I will critically interrogate the efficiency and accountability of these forms of governance in one particular domain, the social inclusion of Roma. The lacking capacity of NGOs and local authorities to implement policies that can address the highly complex situation of Roma, as well as the lack of democratic accountability and non-binding character of these 'soft' modes of governance put serious doubts on the national governments will to improve their situation.

\section{The socialist modes of governing Roma related affairs}

As many socio-historical scholars observed, Roma were regarded with suspicious eyes by the state/local authorities because of their foreign, nonEuropean nomadic way of life (Fraser 2010, Mayall 2004, Saul and Tebbutt 2004, Taylor 2014, Willems 1997). Since the formation of the nation-states and the uprising of the industrial revolution, the Roma were seen as part of the 'nomadic, informal economy, and perceived as outcasts who had escaped from [...] the industrial culture' (Clark 2004, 236) and for whom 'political and legislative interventions [were being designed] by a nervous sedentarist state' (Clark 2004, 244). Although many of the Romanian Roma were already settled before the formation of Greater Romania in 1918 - due to their five centuries long experience as slaves of the local nobility (boieri) and the of the monasteries - during the inter-war period, they increasingly drew attention of state authorities and social scientists, because of their nomadic and seminomadic way of life and their foreign culture, which were simply incompatible with the Romanian nation (Solonari 2015, Turda 2014) and sometimes they were even framed as a threat to the health of the nation (Thorne 2011). In the climax of the pro-Nazi regime led by Ion Antonescu (1941-1944), more than 25,000 Roma were deported to Transnistria, a 
territory occupied by the Romanian army, with the single goal of "purifying the nation' (Solonari 2015). However, their failure to be assimilated (as in sedentarizied) paved the way for the assimilationist program of the socialist regimes.

The new socialist regime could not repress the national idea - although appealed to its international origin - because of its latter presence in the political, sociological, anthropological, geographical, literary or historical discourse in the inter-war period (Verdery 1994, Cotoi 2006), but did manage to give a new sense to nation/ethnicity. By homogenizing the social space and policies to reduce disparities and inequalities between different social groups, the Communist Party claimed to represent the interests of society as a whole. Homogenization did not serve a nation-state based on citizenship or ethnicity, but rather to a socialist nation, where all members were dependent on the goods and services offered by the state (Verdery 1993, 191). However, in the case of Roma, they benefited ambiguously by the socialist policies, their socio-economic status has improved with the price of losing their identity and in most of the cases, by preserving their secondclass citizen status.

Even if they are few quantitative researches that have analyzed the socio-economic status of Roma during the socialist regime (Achim 2004, Guy 2009b, Barany 2002), it may be obvious that the socialist policies had a positive effect, due to their redistributive logic. One can delineate two processes that dominated the socialist assimilationist program, in its attempt to turn this poor and marginalized minority into good socialist citizens (Stewart 1997, 6). The first process regards the sedentarization of nomadic and semi-nomadic groups. From a Marxist point of view, nomadism was associated with marginality and poverty. The changes due to industrial capitalism in the second half of the $\mathrm{XIX}^{\text {th }}$ century and the first half of the $\mathrm{XX}^{\text {th }}$ century transformed Roma artisans, basket makers, metallurgists into beggars, forced to steal or to take advantage of others by developing commercial or trading skills, deemed as immoral by the socialist authorities Not being integrated into the formal economy, Roma were perceived by the 
socialist authorities as part of the lumpenproletariat (Stewart 1997, Lucassen 1998). Sedentarization was one of the key strategies used by modern nationstate to strengthen and centralize power by controlling the knowledge of its population (see Scott 2007).

The second process is that of proletarization. Roma nomadism was not just about potential deviancy, but also, trade and business activities were signs of independence from the socialist production system. By confiscating their trade and livelihood means, be it gold, horses or other means of production and engaging them into the socialist production system, by giving Roma jobs in industry or cooperatives, they were proletarianized. Strict labour discipline, organization and collective work was needed to combat 'social parasitism' and change their lifestyle (Stewart 1997, Barany 2002).

As early as the 1930s, the 'soviet legislation against parasites' deemed Roma, itinerants, orphans and beggars as a 'social threat to social order' and sent them to the Gulag (Fitzpatrick 2006). In time, the category of 'parasitical' was extended so that it came to include persons who refused to do 'socially-useful work', among which were included idle youth, traders, speculators, private entrepreneurs and other persons who worked in the informal economy (Fitzpatrick 2006, 389, 393). Romania was one of the first countries in the Soviet bloc that tried to sedentarize Roma by confiscating their horses and wagons and dispersing compact communities. In the early 1950s, most of the Roma were already sedentary. The main objective of the socialist regime in Romania - as in other countries in the region - was full employment of its labour force. In Romania, Decree No. 153 from 1970 condemned 'social parasitism' and deviation from the socialist way of life by imprisonment and forced labour but even so, the policy was not implemented rigorously by local authorities (Barany 2000).

The only official policy document aimed directly at the Roma was the report issued by the Central Committee of the Romanian Communist Party in 1983, which was basically an evaluation of its large-scaled programs to integrate Roma after 1977. The 'Roma problem' became an interest for 
country officials as a consequence of the $80.2 \%$ increase of Roma population in 1977 compared to 1966 . The number of Roma was 227,398 , or $1.05 \%$ of the total population (Crowe 1995, 139). Two years before the census, the Ministry of Interior issued another census that indicated a number of 541,000 Roma, of which 66,000 were semi-nomads and 470 were nomads (Stoenescu 2015 , 428). Roma unemployment was very high, according to the above evaluation, $32 \%$ of men and $48 \%$ of women were unemployed. The situation of semi-nomads and nomads Roma was even worse, as $84 \%$ of them were found not being formally employed. Therefore, a Commission on Demography with local branches was established 'to study the problems of integrating Gypsies' (Crowe 1995, 139). Despite these programmes set in place in the middle of the 1970s, the report blamed the Roma for maintaining non-socialist attitudes, such as social parasitism, nomadic way of life and avoiding registering at the local institutions (Fosztó and Anăstăsoaie 2001, 356). The report framed Roma in socio-economic, rather than ethnic terms, as a deviant category.

Some scholars like Viorel Achim consider that the failure of the socialist policies to integrate the Roma can be attributed to the particular characteristics of this minority, namely what he calls the 'explosive demographic growth' and their 'demographic behaviour', which was different from the demographic patterns of modern Romania, creating a 'civilization gap between the Gypsies and the majority population' (Achim 2004, 199). However, Achim does not show how the Roma was problematized, not in cultural or ethnic terms during the socialist regime but rather as a deviant category, characterized by anti-social behaviour and lack of civilization. The problematization of the 'Roma question' in social rather than ethnic or cultural terms, allowed the state authorities to legitimate their interventions in the lives of the Roma and to depoliticize the discriminatory practices associated with this interventions:

Roma/Gypsies are thought to have no linguistic, cultural or ethnic roots. They are instead a 'social problem' requiring 'rehabilitation' and 'reintegration', who can - and must - be brought back into the fold of 'society'. The consequences of this are extremely negative, because it is 
these images which inspire, channel, and justify action. This is how cultural questions are reclassified as 'social problems'; it is this vision which lies behind the assume duty - and thus the right - of active intervention, and gives rise to measures of 'assistance' opening up the way for full-scale drives aimed at 'reintegration' and 'rehabilitation'. These flawed analyses encourage a focus on the consequences of a given situation (such as health problems, poverty, illiteracy, etc., rather than on their root causes (rejection, inappropriate provision, etc.). Another perverse effect of the development and use of this kind of imagery: since it categorizes Roma/Gypsies in social rather than ethnic or cultural terms, means that neither their authors, nor the law, consider the resulting measures are discriminatory (Liégeois and Gheorghe 1995, 12-13).

The socialist campaign to assimilate the Roma - mainly through enforced employment and education - had its ambiguous results. By not being accorded the status of national minority, the Roma could not benefit from education in their own language. By encouraging them to take semi or unskilled jobs in the heavy industry or state cooperatives - which were the first ones made redundant after 1989 - and by offering them substandard housing on the outskirts of towns and villages or of much poorer quality than those offered to the majority population shows the Roma were rather seen as second-class citizens. These past injustices were to be addressed by the new policies and programmes set in place after 1989 by national governments, local and international NGOs and especially by intergovernmental organizations. In the next section, I will sketch the changes in minority representations and forms and instruments of governance that facilitated such changes.

\section{Changes in minority representations, forms and tools of governance}

After the fall of the socialist regimes we can observe a new perspective on governing Roma related affairs, from the old narratives and programmes of discipline, control or policing, or alongside them, to more (neo)liberal forms of governing, based on narratives of empowerment, self-government, capacity building, increasing self-esteem and active inclusion. When the 
Council of Europe $(\mathrm{CoE})$ transformed minority protection into a cornerstone for the membership into the European Union for the CEE states - alongside a functional market economy and democratic institutions (Council of Europe 1993b) - all future applicant states had to change their policies for national minorities. The further Europeanization of Romani representations continued in the same year when CoE issued Recommendation 1203 on the situation of Gypsies in Europe, remarking that 'living scattered all over Europe, not having a country to call their own, they are a true European minority [...] [who] greatly contribute to the cultural diversity of Europe' (Council of Europe 1993a). The Organization for Security and Co-operation in Europe (OSCE) has established in 1994 a Contact Point for Roma and Sinti Issue in its Office for Democratic Institutions and Human Rights. The changing minority representation of Roma as a European one marks a new turning point for state policies. Indeed, as I have already suggested above, if during the formation of nation-states, communism and Nazism, the Roma were framed as a non-European, foreign minority, whose place was not (yet) in Europe (Mayall 2004, Saul and Tebbutt 2004, Willems 1997), after 1989, European institutions, IGOs and Romani NGOs started framing Roma as a European minority. Recently, the Socialist \& Democrats Party in the European Parliament has published a book, entitled 'Roma: A European Minority' (Flasikova-Benova, Swoboda, and Wiersma 2011). When asking who the Roma are, the World Bank will respond in one of its extensive report with 'the largest and most vulnerable minority in Europe' (Ringold, Orenstein, and Wilkens 2005, 3). As a consequence, heterogeneous Romani, Sinti, and Traveller groups throughout Europe have been framed in terms of their European belonging and European (minority) identity.

The active involvement of EU institutions and IGOs was certainly a result of the numerous inter-ethnic conflicts present in CEE countries at the beginning of the 1990. In Romania alone, until 1995, Richard Hajek (1998) identified 37 mob and institutional (police abuses) attacks against Roma communities. With the mid-1990s, EU institutions - who previously did not have any minority policies - started promoting 'hard' modes of governance 
toward CEE candidate states, through adopting minority and human rights laws and harmonization of social policies. The European Convention on Human Rights (1994), the Framework Convention for the Protection of National Minorities (1995) and the Racial Equality Directive 2000/78/EC are examples in this sense. Later, during accession negotiations with the CEE countries, the European institutions have approached the Roma within the wider European integration framework. The EU encouraged governments in the former socialist countries to develop strategies at national and local level as part of the requirements for EU membership. Still, the EU accession conditionality has had an ambiguous effect. Scholars from the Europeanization literature show that rule transfer from EU to non-member states are more effective if they pose a threat to future membership if not complying with them (Schimmelfennig and Sedelmeier 2004, Schimmelfennig 2001). However, the Copenhagen criteria did not have clear targets or processes by which this conditionality could be strengthened or enforced. Simultaneously, the acquis communautaire did not contain rules for the respect of minority rights, so that delicate issues related to inter-ethnic relations were left in the responsibilities of national governments, limiting the impact of EU accession (Rechel 2008). In addition, the EU harmonization by law met the blatant reality of a highly diversified recognition of Roma minority as an ethnic, cultural or linguistic group.

However, alongside the hard modes of governance, the EU has adopted 'soft' modes of minority governance by directly engaging civil society actors and Roma representatives in the policy fabric. Since the beginning of the 1990s, the IGOs have called explicit engagement of the Roma and pro-Roma NGOs in the policies designed for them. The active involvement of Roma has to do with the new approach to governance developed in the second half of the 1990s that had an impact on minority policies at European and national level. In this context, minority governance refers to a set of tools and methods that facilitate the participation of minorities in society to prevent and/or reduce conflicts between minorities and the majority population, to institutionalize the protection of minorities, 
so minorities themselves can become agents and representatives in decisionmaking processes that concern them directly (van Baar 2011a, 9). It is under this umbrella that Roma experts were hired in local and national public institutions. Roma activist from human rights and development NGOs that were implementing Roma projects in the 1990s, were the ones who crossed sectors later, entering public administration ${ }^{2}$.

The active participation of the Roma civil society and representatives is in line with the new approach of the European institutions regarding the reform of global social policy to describe the latter towards active welfare states, embodied in the Lisbon Strategy (European Commission 2000a). These processes cannot be related only with minority governance, but with a broader objective of transforming European governance. Since the Lisbon Strategy, the EU started to be concerned about its democratic deficit and lack of legitimacy. Strengthening civil society, private and public local actors, are part of the EU effort to make the structures of governance more democratic, efficient and legitimate in representing people interests and more broadly to bring the EU closer to its citizens. These were the main targets of the White Paper on European Governance, released by the European Commission in 2001 (European Commission 2001). Since then, softer instruments of governance have been developed, such as public-private partnerships, the Open Method of Coordination 'to introduce more democratic parameters in decision-making, and to regain the lost popular confidence in the European integration project' (Borrás and Jacobsson 2004, 186). The latter was introduced as a compromise in coordinating social policies, since the EU did not have any levers for binding regulations in this domain, which was rather subsumed to the principle of subsidiarity. As van Baar emphasized '[these soft modes of governance] are the preferred «channels〉 for reaching specific EU aims, often in deliberate substitution for state-initiated action. Through the

\footnotetext{
2 Although the bulk of Roma experts were hired after the first National Strategy for improving the situation of Roma (2001), there were some initiatives in hiring Roma experts before this date. In 1991, through a Ministry Order, the County Councils were recommended to hire a Roma expert in the local branches of the National Employment Agency, a measure followed up by half of the Counties (Zamfir 2014, 16)
} 
active mobilization of <civil society>, the EU tries to extend the scope of its governmental power beyond its own jurisdiction and the formal and legal structures of its member states' (van Baar 2011b, 8, my emphasis). As I will show in the next section, these soft instruments of governance are used when hard instruments are lacking. While their efficiency is often contested, they tend to reinforce the socio-economic and political exclusion of Roma.

\section{Contesting practices of neo-liberal governance}

Since the Lisbon Council, the EU and IGOs have enforced their governance of Romani social inclusion. Most of the policy-documents reflected a more neoliberal discourse in solving minority and social affairs through the processes of decentralization, public-private partnerships and mobilization of civil society organizations in policy design and implementation (European Commission 2000b, 2003, 2005, World Bank 2005). In most cases, these policy options were supported by IGOs, EU institutions or other external donors by introducing them as eligibility criteria for obtaining projects.

In Romania, some of these practices were established since the early 1990s. In this period, many NGOs were 'born' as a result of the increasing international donor funding. In Roma related affairs, international NGOs like Helsinki Watch, Project on Ethnic Relations, European Roma Rights Center, and Partners for Democratic Change were active in the human rights and advocacy domains. A research carried out in 2001 showed that during the first decade of transition, more than one thousand projects for Roma were implemented by 519 organizations; the NGOs had implemented $79 \%$ of these projects (Bădescu 2001, 36-37). Many of their initiatives were taken over by state authorities and transformed in public policies: school and health mediators, 'the second chance' school program, Roma job fairs. Mobilizing civil society has become an important pillar on the IGOs agenda after the fall of socialism, which needed to be revived, supported, encouraged, and developed through trainings and capacity building. This 
was done through creating new logistic and management structures that will finance and increase capacity of these NGOs. The focus of IGOs on mobilizing civil society and the involvement of NGOs or various forms of representation is based on the rationale that the latter will be involved in developing and implementing development strategies, and also will enable grass-roots democratization (Weiss 2000).

However, although these soft modes of governance were launched during the Lisbon Strategy as a deliberative-democratic and non-coercive way to facilitate Roma inclusion, they tend to displace and de-politicize delicate issues and social conflicts between the EU and its member states (van Baar 2011b, 11) by devolving complex problems of inequality, socioeconomic marginalization and segregation to NGOs and local authorities. The case of ethnic segregation in schools is highly relevant here due to Romania's commitment for school desegregation in the last decade. According to the UNDP/World Bank/European Commission regional survey from 2011, 22\% of Romanian Roma children between the ages of 7 and 15 attend regular schools with majority Roma student body (Ivanov and Kagin 2014, 38). School segregation was on the agenda of IGOs and other foreign donors since the beginning of the 2000s when Romani human rights NGOs observed human rights violations by segregating Romani students in special schools for Roma or in special classes in the case of mainstream schools. Using the rhetoric of human and minorities rights in the context of European integration, the NGOs could pressure public authorities to adopt national legislative measures to combat school segregation. Romania adopted such measures in response to EC's Directive 43/2000. A law that prohibited discrimination based on race, ethnicity, religion or disability was passed in 2006 in the Parliament to meet the above-mentioned European Directive. Instead, the Minister of Education adopted non-binding rules to combat discrimination: a circular from 2004 which forbade establishing kindergarten classes and primary and secondary classes on ethnic grounds, and a Ministerial decree from 2005 that forbids segregated classes in the $1^{\text {st }}$ and $5^{\text {th }}$ grade. 
If in other countries from CEE, like Bulgaria and Hungary, measures against school segregation have been converted into laws, in Romania, segregation is defined in a circular of the Minister and in a ministerial order with a less binding status than a law. In the absence of anti-discrimination laws in education, public authorities have no specific obligation to prevent and eliminate segregation in education and the above-mentioned measures are not followed by sanctions (Taba and Ryder 2012, 29-31, European Roma Rights Center 2007). With no independent body to monitor the implementation of governmental strategies in education and of raw data to provide a diagnostic of the process, school segregation seems to continue in a more or less visible form. In Aiud most Roma students are enrolled in one of the local schools, known as the 'Gypsy school' as a result of a residential segregation. Segregation of spoitori Roma children in Oltenița is justified by the school principal as a result of cultural differences between the Roma and Romanian children, noting that it is better for Roma children to be segregated' (Vincze 2014a, 87). Because of the lack of binding laws that would prohibit school segregation, most of the initiatives are project-based and passed on to local authorities and NGOs. Even the National Actions Plans that resulted from the Decade of Roma Inclusion did not have clear targets, indicators and an established budget. Moreover, local authorities could segregate Romani students on the ground of implementing legal provisions for the education in minority language. In a town from Alba County, Roma students were segregated in separate classes on the basis of teaching courses in Romani language although they did not speak Romani3.

The European Framework for Roma inclusion (European Commission 2011) represented a deeper Europeanization of Romani minority governance. Local authorities, NGOs and national governments participate in the European Roma Summits, and a European Roma Platform was established for municipalities, governments and local NGOs to exchange best practices in the field of Roma inclusion. The latter adopted the '10 Common Basic Principles on Roma Inclusion' (Open Society Institute 2011)

\footnotetext{
${ }^{3}$ Interview with Roma inspector on Roma problematic from Alba county.
} 
among which involvement of regional and local authorities, of civil society organisations and active participation of the Roma were well emphasized. This led to a more ambiguous responsibility related to Roma affairs. No doubt that the new framework has passed the accountability for Romani inclusion to national governments, who have passed it down to local authorities, decentralized institutions, Roma experts and community representatives (Guy 2009a). This 'web of governance' (Clarke 2012) that results from the passing of responsibilities upwards towards EU and downwards towards local governments and NGOs might entail a crises of democratic accountability (van Baar 2012).

First of all, by Europeanizing social inclusion policies, a 'politics of reinterpretation' (Vermeersch 2012) took shape, where national elites could transfer the responsibilities for Romani inclusion to European institutions, although Roma are citizens of Member States. The National Strategies with its Action Plans, targets, and measures are negotiated within experts groups, policy experts from Ministries and even European Commission, far away from national parliaments, local authorities, not to say Roma citizens, therefore questions of legitimacy can be posed. Second, by advancing financing lines that can be directly absorbed by local authorities and NGOs, conflicts between the EU and national governments are depoliticized and placed in the hands of the latter. This raises questions about local authorities' capacity to attract external funds, because of limited human resources, know-how, and financial resources. Often, small administrative units have to solicit consulting firms to write projects because of their lack of capacity ${ }^{4}$. As some scholars have shown, as a result of a poor institutional capacity of local authorities to develop and implement complex socio-economic development programs, they are left with no choice other than to adopt hostile policies doubled by moralizing discourses about poor adaptability, laziness and lack of will for integration (Vincze 2014a, Vincze and Hossu 2014b).

\footnotetext{
${ }^{4}$ Interview with Roma expert from Cluj-Napoca county.
} 
Last, but not least, the passing of responsibilities for Roma inclusion to Roma experts, representatives or Romani NGOs tends to displace complex issues of marginality, exclusion and discrimination away from state related authorities and place it in the hands of Roma experts and NGOs. The case of Roma who were evicted from the centre of Cluj-Napoca to Pata Rât is an illustrative one when the prefect of Cluj has failed to use his administrative power to postpone the eviction after winter. Later, the case was taken (and won) by European Roma Rights Center ${ }^{5}$ and Romani Criss in court and not by Romanian authorities. A similar case is met in Sânmartin, Harghita county, where an inter-ethnic conflict between Roma and Hungarians in 2009 led to a pogrom where some Roma houses were badly wrecked and the Roma had to flee from their houses (Romani Criss 2009). The case was also taken by Romani Criss ${ }^{6}$ and it is still pending in courts ${ }^{7}$. Left to their own devices, Roma have to appeal to Romani NGOs and Roma experts to solve their problems. According to an evaluation report of POSDRU programmes and projects that benefitted the Roma, half of the beneficiaries of labour market programmes (training, retraining, and counselling) and second chance school programmes were Roma (AM POSDRU 2015, 93, 97).

\section{Conclusions}

During the last 25 years we have been witnessing to large scale European programmes, national policies and numerous - but very fragmented, nonintegrated, less sustainable - projects to improve Roma socio-economic situation in Romania. The assimilationist and disciplinary policies of the socialist regimes were replaced by the new democratic and inclusive policies set in place after 1989. The involvement of various IGOs, European

\footnotetext{
${ }^{5}$ Although the case was won by ERRC it was not a definitive decision and now the case is in retrial, interview with Roma expert from National Agency for Roma.

${ }^{6}$ Romani Criss is the most important Romani NGO from Romania dealing with human and minority rights violations. In time, Romani Criss helped numerous Romani victims to file complaints with national and European courts for human rights violations (perpetrated) by the police or local authorities.

7 Interview with Roma expert from National Agency for Roma.
} 
institutions and NGOs in a common effort to 'turn the tide' for the benefit of Roma was possible due to two processes that I have discussed in this article: (1) the Europeanization of minority representations, meaning the construction of a European identity that would guarantee Roma's belonging to European societies and empowering them to benefit from the political and economic reforms in post socialist Romania and (2) the changing modes of governance in minority related affairs, through adopting soft modes of governance, with the aims of increasing democratic accountability and assuring efficiency of public policies for Roma.

The article delineates some of the pitfalls in this model of minority governance. The growing implication of European institutions in promoting soft governance after the Lisbon Strategy, through capacity building of public institutions and NGOs, establishing networks of public-private partnerships, the growing implication of NGOs in combating discrimination and social exclusion, is a way through which the EU tries to exert governmental power over Member States in domains where it does not have binding regulations and that are more subordinated to the principle of subsidiarity (as social policy and social inclusion). Soft modes of governance raise issues of democratic legitimacy since this heterarchical or network forms of coordination are not based on command and control type of policies and as a consequence, are amenable to a loose political control (see Borrás and Conzelmann 2007). By strengthening civil society organizations and offering funding lines for local authorities, a de-politicization of conflict between EU institutions and governments takes place, where complex problems of inequality, marginalization and segregation are devolved to lower scales of governance. Questions marks can be raised in the case of smaller territorial administrative units (where most Roma live) about their capacity to attract these funds. Rather, their inability to map and implement complex socio-economic developmental programmes left them with no choice other than to 'contain' the Romani communities that are not able to integrate, as the cases of Baia Mare, Cluj-Napoca or Alba Iulia show. 
Left to their own devices, Roma often have appealed to Roma and proRoma NGOs and Roma experts to tackle their socio-economic exclusion and low social mobility. Furthermore, the Europeanization of Roma policies has paved the way for a devolution of responsibilities for Roma socio-economic inclusion away from national governments and national politicians to European level and civil society NGOs (van Baar 2012, Agarin 2014), which raises questions about democratic accountability and political will in bridging the gap between Roma and non-Roma.

\section{References:}

Achim, Viorel. 2004. The Roma in Romanian History. Budapest: Central European University Press.

Agarin, Timofey. 2014. "Travelling without moving? Limits of European Governance for Romani inclusion." Ethnicities 14(6): 737-755.

AM POSDRU. 2015. Evaluare ad-hoc a intervenției POSDRU privind populația Roma. Raport de evaluare. București: Autoritatea de Management POSDRU.

Amnesty International. 2015. The state of the world's human rights. London: Amnesty International.

Bache, Ian and Matthew Flinders. 2004. Multi-Level Governance. Oxford: Oxford University Press.

Bădescu, Gabriel. 2001. "A Quantitative Analysis of the Roma projects." In Roma Projects in Romania, 1990-2000, edited by Viorel Anăstăsoaie and Daniela Tarnovschi, 35-68. Cluj-Napoca: Ethnocultural Diversity Resource Center.

Barany, Zoltan. 2000. "Politics and the Roma in State-Socialist Eastern Europe." Communist and Post-Communist Studies 33(4): 421-437.

Barany, Zoltan. 2002. The East European Gypsies. Regime Change, Marginality and Ethnopolitics. Cambridge: Cambridge University Press.

Borrás, Susana and Thomas Conzelmann. 2007. "Democracy, Legitimacy and Soft Modes of Governance in the EU: The Empirical Turn." Journal of European Integration 29(5): 531-548.

Borrás, Susana and Kerstin Jacobsson. 2004. "The open method of coordination and new governance patterns in the EU." Journal of European Public Policy 11(2): 185-208. 
Börzel, Tanja. 2011. "Drawing Closer to Europe: New Modes of Governance and Accession." In New Modes of Governance in Europe. Governing in the Shadow of Hierarchy, edited by Adrienne Héritier and Martin Rhodes, 75-103. London: Palgrave Macmillan.

Bruszt, Laszlo. 2008. "Multi-level Governance-the Eastern Versions: Emerging Patterns of Regional Developmental Governance in the New Member States." Regional and Federal Studies 18(5): 607-627.

Clark, Colin. 2004. "'Severity has often enraged but never subdued a gypsy': The History and Making of European Romani Stereotypes." In The Role of the Romanies Images and Counter-Images of 'Gypsies'/Romanies in European Cultures, edited by Nicholas Saul and Susan Tebbutt, 226246. Liverpool: Liverpool University Press.

Clarke, John. 2012. "The work of governing." In Governing Cultures: Anthropological Perspectives on Political Labor, Power, and Government, edited by Kendra Coulter and William Schumann, 209-232. New York: Palgrave Macmillan.

Cotoi, Călin. 2006. Primordialism cultural și geopolitică românească. Lecturi în oglindă. București: Mica Valahie.

Council of Europe. 1993a. Recommendation 1203 on Gypsies in Europe. Strasbourg: Council of Europe.

Council of Europe. 1993b. European Council in Copenhaga. Conclusions of the Presidency. Copenhaga: Council of Europe.

Crowe, David. 1995. A History of the Gypsies of Eastern Europe and Russia. London and New York: 1B.Tauris \& Co Ltd.

European Commission. 2000a. The Lisbon European Council: An Agenda for Economic and Social Renewal in Europe. Bruxelles: European Commission.

European Commission. 2000b. The Commission and non-governmental organisations: building a stronger partnership. Luxembourg: European Commission.

European Commission. 2001. European Governance. A White Paper Bruxelles: European Commission.

European Commission. 2003. Governance and Development. Brussels: European Commission.

European Commission. 2005. Communication to the spring European Council. Working together for growth and jobs. A new start for the Lisbon Strategy. Brussels: European Commission.

European Commission. 2011. An EU Framework for National Roma Integration Strategies up to 2020. Bruxelles: European Commission. 
European Roma Rights Center. 2007. The Impact of Legislation and Policies on School Segregation of Romani Children. A Study of AntiDiscrimination Law and Government Measures to Eliminate Segregation in Education in Bulgaria, Czech Republic, Hungary, Romania and Slovakia. Budapest: European Roma Rights Center.

Fitzpatrick, Sheila. 2006. "Social Parasites: How Tramps, Idle Youth, and Busy Entrepreneurs Impeded the Soviet March to Communism." Cahiers du Monde russe 47(1/2): 377-408.

Flasikova-Benova, Monika, Hannes Swoboda, and Jan Marinus Wiersma, eds. 2011. Roma: A European Minority. The Challenge of Diversity. Bruxelles: European Union.

Fosztó, László, and Viorel Anăstăsoaie. 2001. "Romania: representations, public policies and political projects." In Between past and future: The Roma of Central and Eastern Europe, edited by Will Guy, 351-369. Hatfield: University Of Hertfordshire Press.

Fraser, Angus. 2010. Țiganii. Originile, migrația și prezența lor în Europa. București: Humanitas.

Guy, Will. 2009a. "EU Initiatives on Roma: Limitations and Ways Forward." In Romani Politics in Contemporary Europe. Poverty, Ethnic Mobilization and the Neoliberal Order, edited by Nando Sigona and Nidhi Trehan, 23-50. Basingstoke: Palgrave Macmillan.

Guy, Will. 2009b. "Roma: Living Conditions, Social Perception and State Policy in the Macro-Region of "Eastern Europe" before and after 1989." Südosteuropa Mitteilungen 49(2): 54-65.

Hajek, Richard. 1998. Roma in Eastern Europe: Ethnic Policy and Security in the Czech Republic, Slovakia and Romania. National Security Affairs, Naval Postgraduate School, California.

Héritier, Adrienne, and Martin Rhodes, eds. 2011. New Modes of Governance in Europe. Governing in the Shadow of Hierarchy. London: Palgrave Macmillan.

Hooghe, Liesbet, and Gary Marks. 2001. Multi-Level Governance and European Integration. Oxford: Rowman \& Littlefield Publishers.

Hooghe, Liesbet, and Gary Marks. 2003. "Unraveling the State, but How? Types of Multi-level Governance." American Political Science Review 97(2): 233-243.

Ivanov, Andrey, and Justin Kagin. 2014. Roma poverty from a human development perspective. Roma Inclusion Working Papers. Instanbul: UNDP. 
Jessop, Bob. 1999. "The Dynamics of Partnership and Governance Failure." In The New Politics of Local Governance in Britain, edited by Gerry Stoker, 11-32. Oxford: Oxford University Press.

Jessop, Bob. 2004. "Multi-Level Governance and Multi-Level Metagovernance." In Multi-Level Governance, edited by Ian Bache and Matthew Flinders, 49-74. Oxford: Oxford University Press.

Jessop, Bob. 2009. "From Governance to Governance Failure and from Multilevel Governance to Multi-scalar Meta-governance." In The Disoriented State: Shifts in Governmentality, Territoriality and Governance, edited by Bas Arts, Arnoud Lagendijk and Henk van Houtum, 79-100. New York: Springer.

Kohler-Koch, Beate and Berthold Rittberger. 2006. "Review Article: The 'Governance Turn' in EU Studies." Journal of Common Market Studies 44(1): 27-49.

Liégeois, Jean-Pierre, and Nicolae Gheorghe. 1995. Roma/Gypsies: A European Minority. London: Minority Rights Group.

Lucassen, Leo. 1998. "A Blind Spot: Migratory and Travelling Groups in Western European Historiography." In Gypsies and Other Itinerant Groups. A Socio-Historical Approach, edited by Leo Lucassen, Wim Willems and Annemarie Cottaar, 135-152. New York: Palgrave.

Mayall, David. 2004. Gypsy Identities 1500-2000. From Egipcyans and Moonmen to the Ethnic Romany. London: Routledge.

Mionel, Viorel. 2013. România ghetourilor urbane - Spațiul vicios al marginalizării, sărăciei şi stigmatului. București: Pro Universitaria.

Open Society Institute. 2011. EU Policies for Roma Inclusion. Open Society Institute. https://www.opensocietyfoundations.org/sites/default/ files/2011-07\% 2520EU\% 2520Roma \%2520Inclusion \%2520Policies $\% 25$ 20final.pdf

Ram, Melanie. 2011. "Roma advocacy and EU conditionality: Not one without the other?" Comparative European Politics 9 (2):217-241.

Raț, Cristina. 2013. "Bare Peripheries: State Retrenchment and Population Profiling in Segregated Roma Settlements from Romania." Studia Sociologia 58(2): 155-174.

Rechel, Bernd. 2008. "What Has Limited the EU's Impact on Minority Rights in Accession Countries?" East European Politics and Societies 22(1): 171191.

Ringold, Dena, Mitchell Orenstein, and Erika Wilkens. 2005. Roma in an Expanding Europe: Breaking the Poverty Cycle. Washington: International Bank for Reconstruction. 
Romani Criss. 2009. Conflict interetnic în localitatea Sânmartin, jud. Harghita. București: Romani Criss.

Saul, Nicholas, and Susan Tebbutt, eds. 2004. The Role of the Romanies. Images and Counter-Images of 'Gypsies'/Romanies in European Cultures. Liverpool: Liverpool University Press.

Schimmelfennig, Frank. 2001. "The Community Trap: Liberal Norms, Rhetorical Action, and the Eastern Enlargement of the European Union." International Organization 55(1): 47-80.

Schimmelfennig, Frank and Ulrich Sedelmeier. 2004. "Governance by conditionality: EU rule transfer to the candidate countries of Central and Eastern Europe." Journal of European Public Policy 11(4): 661-679.

Scott, James. 2007. În numele statului. Modele eșuate de îmbunătățire a condiției umane. Iași: Polirom.

Shore, Cris. 2011. "'European Governance" or Governmentality? The European Commission and the Future of Democratic Government." European Law Journal 17(3): 287-303.

Solonari, Vladimir. 2015. Purificarea națiunii. Dislocări forțate de populație și epurări etnice în Romania lui Ion Antonescu, 1940-1944. Iași: Polirom.

Stewart, Michael. 1997. The Time of the Gypsies. Colorado: Westview Press.

Stoenescu, Alex Mihai. 2015. Țiganii din Europa și din România. Studiu imagologic. București: Editura Rao.

Stubbs, Paul. 2005. "Stretching Concepts Too Far? Multi-Level Governance, Policy Transfer and the Politics of Scale in South East Europe." Southeast European Politics VI(2): 66-87.

Taba, Marius and Andrew Ryder. 2012. "Institutional Responses to Segregation: The Role of Governments and Non-Governmental Organizations." In Ten years after : a history of Roma school desegregation in Central and Eastern Europe, edited by Iulius Rostas, 7-48. Budapest: Central European University Press.

Taylor, Becky. 2014. Another Darkness, Another Dawn. A History of Gypsies, Roma and Travellers. London: Reaktion Books.

Thorne, Benjamin. 2011. "Assimilation, invisibility, and the eugenic turn in the "Gypsy question" in Romanian society, 1938-1942." Romani Studies 21(2): 177-206.

Turda, Marius. 2014. Eugenism si Modernitate. Națiune, Rasă și Biopolitică în Europa (1870-1950). Iași: Polirom.

van Baar, Huub. 2011a. Minority Representation, Memory and the Limits of Transnational Governmentality. Amsterdam: University of Amsterdam. 
van Baar, Huub. 2011b. "Cultural policy and the governmentalization of Holocaust remembrance in Europe: Romani memory between denial and recognition." International Journal of Cultural Policy 17(1): 1-17.

van Baar, Huub. 2012. "Socio-Economic Mobility and Neo-Liberal Governmentality in Post-Socialist Europe: Activation and the Dehumanisation of the Roma." Journal of Ethnic and Migration Studies 38(8): 1289-1304.

Verdery, Katherine. 1993. "Nationalism and National Sentiment in Postsocialist Romania." Slavic Review 52(2): 179-203.

Verdery, Katherine. 1994. Compromis și rezistență. Cultura română sub Ceaușescu. București: Humanitas.

Vermeersch, Peter. 2012. "Reframing the Roma: EU Initiatives and the Politics of Reinterpretation." Journal of Ethnic and Migration Studies 38(8): 1195-1212.

Vincze, Enikő. 2014a. "Faces and Causes of Roma Marginalization. Experiences from Romania." In Faces and Causes of Roma Marginalization in Local Contexts, edited by Júlia Szalai and Violetta Zentai, 67-96. Budapest: Center for Policy Studies.

Vincze, Enikő, and Iulia-Elena Hossu, eds. 2014b. Marginalizarea socioteritorială a comunităților de romi din România: studii de caz în județele Alba, Arad, Călăraşi, Dolj şi Iași Cluj-Napoca: Editura Fundației pentru Studii Europene.

Weiss, Thomas. 2000. "Governance, good governance and global governance: Conceptual and actual challenges." Third World Quarterly 21(5): 795-814.

Willems, Wim. 1997. In search of the true Gypsy: from Enlightenment to Final Solution. London: Routledge.

World Bank. 2005. Empowering People by Transforming Institutions:. Social Development in World Bank Operations. Washington DC: The International Bank for Reconstruction and Development.

Zamfir, Cătălin. 2014. Evaluarea capacității Agenției Naționale pentru Romi. București: Institutul de Cercetare a Calității Vieții. 